相

\title{
ANALISIS KEBIJAKAN OPTIMALISASI UTILISASI SUMBER DAYA MANUSIA DAN FASILITAS RISET NASIONAL
}

\author{
Edy Suandi Hamid ${ }^{1}$ \\ Chairil Anwar ${ }^{2}$ \\ ' 1 Universitas Islam Indonesia, Yogyakarta \\ 2 Universitas Gadjah Mada, Yogyakarta
}

\begin{abstract}
This examination intend to know and analyses utilization investment research rate by research agency in coordination with Ministry of Research and Technology (KRT). and analyze ways and efforts to increase utilization of government investment in research field and reduces technical mistakes. Research conduct in BPPT, BATAN, and LIPI, This research is a policy research with using normative - qualitative approach

From research finding that, quantitatively human resources in non governmental department (LPND) having unbalanced ratio problem based on its functional position, especially in researcher category and non researcher. Quantitatively growth rate of research unmatched with retirement rate, resulted changing age structure tend to older age.

Size limitation and lack of available data about utilization research facilities still not solved completely. Based on evaluation made by KRT, in macro, set up of condition and usage facilities lie near 50\% to 75\%. However, research facilities administrator still not satisfied yet with utilization of research facilities they managed. Other research facilities problems are slow supply, limited maintenance fund and lack of available spare parts.
\end{abstract}

Keywords: inflation, unemployment, productivity, excess demand, excess supply

\section{LATAR BELAKANG MASALAH}

Sejarah membuktikan bahwa negaranegara yang memiliki keunggulan IPTEK (Ilmu Pengetahuan dan Teknologi), berhasil meningkatkan kesejahteraan dan keunggulan ekonomi di antara negara lainnya. Oleh karena itu, untuk mewujudkan tujuan nasionalnya, maka bagi Bangsa Indonesia perlu mengembangkan IPTEK tersebut. Implikasi IPTEk terhadap kesejahteraan ini juga ditegaskan dalam UU No. 25 Tahun 2000 tentang Program Pembangunan Nasional (Propenas) 2000-2004. Iptek diharapkan berperan dalam hal mempercepat pemulihan ekonomi dan memperkuat landasan pembangunan berkelanjutan dan berkeadilan, serta membangun kesejahteraan rakyat dan ketahanan budaya.

Kesadaran itulah yang menyebabkan banyak negara bersaing untuk meningkatkan capaian IPTEK-nya. Indikator yang dapat digunakan untuk menilai keunggulan IPTEK suatu bangsa adalah seberapa besar produktivitas suatu negara dalam bidang riset. Sebab kegiatan riset adalah penopang utama pengembangan IPTEK. Tabel di bawah ini 
dapat memberi gambaran bagaimana suatu negara memberikan alokasi anggaran untuk riset sebagai usaha meneguhkan dominasi penguasaan ilmu pengetahuan di dunia.

Data pada tabel di bawah mengungkapkan bahwa persentase pengeluaran untuk penelitian di Indonesia hanya $0,2 \%$ dari Gross Domestic Product (GDP), angka tersebut merupakan angka terendah di antara negara-negara Asia Tenggara. Negara dengan pengeluaran tertinggi di bidang riset adalah Jepang, bahkan negeri jiran kita, Malaysia, Indonesia juga tertinggal jauh.

Tabel 1. Pengeluaran di Bidang Ristek di Beberapa Negara Asia

\begin{tabular}{|l|c|}
\hline Negara & $\begin{array}{c}\text { Persentase Pengeluaran } \\
\text { terhadap GDP }\end{array}$ \\
\hline Japan & 2,9 \\
South Korea & 1,9 \\
Taiwan & 1,7 \\
Malaysia & 1,2 \\
Singapore & 1,0 \\
India & 0,9 \\
Thailand & 0,7 \\
RRC & 0,7 \\
Indonesia & 0,2 \\
\hline
\end{tabular}

Sumber: World Bank Mimeo,1995, Institution Policy for Industrial Technology Development

Kementerian Riset dan Teknologi dalam melaksanakan amanat Garis-garis Besar Haluan Negara (GBHN) serta Propenas yang terkait dengan penguasaan ilmu pengetahuan dan teknologi memahami keterbatasan anggaran pemerintah dalam bidang riset. Keterbatasan tersebut diperparah oleh krisis ekonomi yang sudah berlangsung beberapa tahun terakhir ini.

Penajaman program dan kejelasan sasaran serta tolok ukur juga menjadi agenda penting bagi LPND yang menurut Keputusan Presiden No. 166 Tahun 2000 , berada dalam koordinasi Menristek. Lembaga tersebut adalah Lembaga Ilmu Pengetahuan Indonesia (LIPI), Badan
Pengkajian dan Penerapan Teknologi (BPPT), Lembaga Penerbangan Antariksa Nasional (LAPAN), Badan Koordinasi Survei dan Pemetaan Nasional (BAKOSURTANAL), Badan Standardisasi Nasional (BSN), Badan Pengawas Tenaga Nuklir. (BAPETEN) dan Badan Tenaga Nuklir Nasional (BATAN).

Menurut Laporan KRT tahun 2000, disebutkan bahwa penilaian kinerja LPND yang pernah dilakukan belum memberikan informasi yang cukup untuk menggambarkan utilisasi sumber daya manusia dan fasilitas riset. Salah satu faktor yang mempengaruhi adalah keterbatasan informasi yang menjadi sumber assessment, yaitu laporan tahunan masing-masing LPND. Karena itu diperlukan penelitian yang lebih lengkap tentang masalah pemanfaatan SDM dan fasilitas riset ini.

\section{TUJUAN PENELITIAN}

Berdasar latar belakang di atas, maka studi kebijakan ini bertujuan untuk

1. Mengetahui dan menganalisis tingkat pemanfaatan investasi riset oleh lembaga atau institusi riset yang ada dalam koordinasi KRT.

2. Mengetahui dan menganalisis cara dan upaya untuk meningkatkan kreativitas dalam pemanfaatan investasi pemerintah di bidang riset dan mengurangi kesalahankesalahan yang bersifat teknis.

3. Mengetahui dan menganalisis berbagai alternatif kebijakan dalam rangka meningkatkan utilitas SDM dan fasilitas riset pada LPND dalam koordinasi KRT.

\section{LANDASAN TEORETIK}

\section{Analisis Kebijakan}

Analisis kebijakan merupakan proses kajian yang meliputi lima komponen informasi kebijakan (policy informational components) yang ditransformasikan dari satu ke lainnya dengan menggunakan lima prosedur analisis kebijakan (Dunn, 2000). Prosedur dalam 
analisis kebijakan secara umum terdiri dari lima bagian (Wallace, 1971), yaitu: perumusan masalah, peramalan (prediksi), pemantauan (deskripsi), evaluasi, dan rekomendasi (preskripsi).

Penggunaan analisis kebijakan memungkinkan terjadinya transformasi satu tipe informasi ke tipe informasi lainnya. Informasi dan prosedur bersifat saling tergantung. Oleh karena itu, komponen-komponen informasi kebijakan, seperti masalah-masalah kebijakan, masa depan kebijakan, aksi kebijakan, hasil kebijakan, dan kinerja kebijakan akan dapat ditransformasikan dari satu ke yang lainnya dengan menggunakan prosedur analisis kebijakan.

Bentuk optimal dari analisis kebijakan yang akan digunakan dalam penelitian ini adalah analisis kebijakan terintegrasi, yaitu kombinasi dari pendekatan prospektif dan retrospektif atas kebijakan (Coleman, 1975). Meskipun demikian, karena titik berat dari studi ini pada analisis kinerja, maka nuansa pendekatan retrospektif akan lebih dominan. Analisis retrospektif merupakan penciptaan dan transformasi informasi sesudah aksi kebijakan dilakukan.

Analisis kebijakan yang bersifat integratif (seperti contoh pada bagan di bawah), pada dasarnya mempertentangkan antara evaluasievaluasi retrospektif terhadap kebijakan publik, dan eksperimen-eksperimen program kebijakan. Evaluasi retrospektif terhadap suatu kebijakan dalam sebuah bidang (termasuk Ristek), secara khusus menilai kinerja dan program-program yang sedang berjalan. Sebaliknya, eksperimen kebijakan dan program akan menilai kinerja program dan kebijakan "baru" dalam hal hasil nyatanya.

\section{Reward \& Recognition}

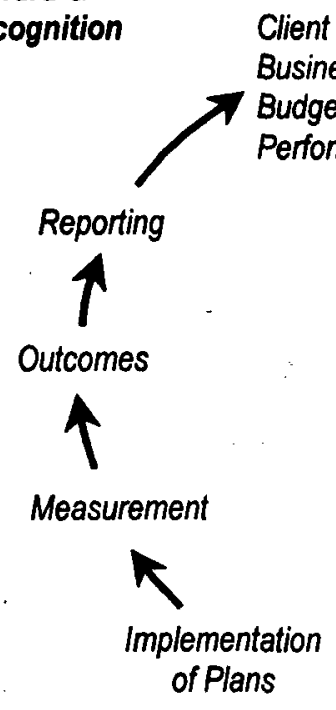

Client need

Business Plan Performance Measure

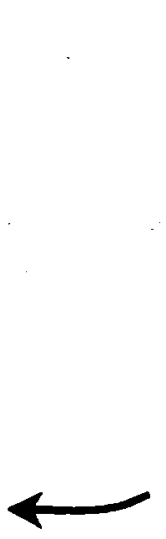

Individual Plan

Performance Measures

Employee Performance

Gambar 1. New Approach to Government

Sumber: PAO Govemment Alberta, 2003 


\section{Evaluasi Kinerja}

Investasi sumber daya manusia yang dilakukan oleh sektor publik dan swasta dapat berupa belanja/pengeluaran pendidikan dalam arti luas, yaitu semua pengeluaran untuk membiayai berbagai kegiatan peningkatan kualitas dan kuantitas sumber daya manusia. Konsekuensi dari investasi sumber daya manusia, pemerintah juga akan mengeluarkan belanja barang modal (capital investment) agar tersedia ruang gerak bagi sumber daya manusia yang dimilikinya untuk melakukan kegiatan produktif sehingga tercapai tujuantujuan pengeluaran investasi.

Untuk mengetahui tipe-tipe pengukuran kinerja dalam bidang SDM dapat dilakukan dengan menggunakan prosedur yang selama ini dipakai oleh para auditor (Erwin Miftah, 2002), meliputi: (a). Human Resource Portfolio, yang merupakan suatu penilaian kinerja yang dilakukan terhadap peran pengelola SDM di perusahaan kita sebut 'divisi SDM'); (b) Human Resources Performance yang dilakukan untuk melihat kinerja karyawan dengan tujuan penilaiannya untuk melihat kompetensi karyawan saat ini sudah sesuai dengan current and future business needs, serta mengkaji apakah kinerja karyawan saat ini sudah memenuhi tujuan tertentu yang telah diset-up sebelumnya; (c). Human Resources Functions, yakni penilaian yang berfokus pada semua fungsi pengelolaan SDM yang ada di perusahaan mulai dari proses perekrutan, penempatan, pendidikan dan pengembangan pegawai, pemberian kompensasi, pembinaan karir, pemberhentian pegawai hingga ke masalah kepemimpinan; (d). Human Resources Utility, yang dilakukan dengan pengukuran atas efektivitas dan efisiensi dari fungsi-fungsi SDM yang ada seperti training and development, recruitment, termination, dan compensation. Dalam hal ini analisa yang digunakan adalah cost-benefit analysis; (e) Human Resources Legal Complience yang merupakan suatu penilaian ini bersifat khusus karena hanya mengevaluasi tingkat ketaatan praktek-praktek SDM terhadap hukum dan peraturan yang ada.

\section{METODE PENELITIAN}

Ada tiga pendekatan yang selama ini dilakukan dalam penelitian kebijakan. Pertama adalah pendekatan deskriptif atau pendekatan positif, yaitu prosedur atau cara yang digunakan oleh penelitian dalam ilmu pengetahuan untuk menerangkan suatu gejala yang terjadi di dalam masyarakat. Pendekatan kedua, adalah pendekatan evaluatif. Pendekatan ini serupa dengan deskriptif, letak perbedaannya adalah adanya kriteria yang ditetapkan untuk melihat temuan. Sedangkan pendekatan ketiga adalah pendekatan normatif, yang disebut juga sebagai pendekatan preskriptif. Pendekatan ini merupakan usaha ilmu pengetahuan untuk menawarkan norma, kaidah atau "resep" yang dapat digunakan oleh pemakai dalam rangka memecahkan suatu masalah. Tujuannya adalah untuk membantu mempermudah user dalam menentukan atau memilih salah satu dari beberapa pilihan atau prosedur yang paling efisien dalam menangani atau memecahkan suatu masalah.

Sebagaimana rumusan masalah yang telah ditetapkan, maka penelitian ini merupakan penelitian kebijakan dengan pendekatan normatif. Secara metodologis analisis kebijakan dapat dibedakan menjadi dua besar, yaitu metodologi kuantitatif dan kualitatif. Penelitian ini lebih sesuai untuk model kualitatif, sebab tidak ada beban generalisasi yang diharapkan. Sebaliknya pemahaman mendalam terhadap masalah penelitian dan model alternatif yang ditawarkan menduduki prioritas yang lebih tinggi.

Data penelitian ini diambil dari dua sumber, sumber pertama adalah data sekunder yang berasal dari laporan-laporan LPND, baik laporan tahunan atau laporan lain yang relevan. Sumber kedua adalah data primer yang diperoleh selama peneliti berada di lokasi penelitian. Data primer merupakan pendalaman 
dan pengembangan dari data sekunder, terutama pada data-data yang tidak tersedia dalam data sekunder. Lokasi penelitian dipilih secara random, yang didasarkan atas asumsi homogenitas problem utilisasi SDM dan fasilitas riset LPND juga dengan pertimbangan waktu dan ketersediaan biaya penelitian. Asumsi homogenitas ini dalam kenyataannya menjadi problem tersendiri, sebab masingmasing laboratorium dalam LPND, misalnya, memiliki karakteristik yang khas. Sehingga homogentitas hanya muncul dalam konteks makro.

Tiga LPND di bawah koordinasi Ristek yang dijadikan sampel adalah LIPI, BATAN dan BPPT. Berdasar struktur organisasi masing-masing LPND, maka lokasi riset dibagi dalam dua level. Level pertama di tingkat Sekretariat Utama, terutama Biro Sumber Daya Manusia, dan Biro Sarana Prasarana. Level kedua adalah riset di tingkat pusat atau laboratorium. Pusat Penelitian dan Pengembangan Teknologi Maju yang ada di Yogyakarta dipilih sebagai sampel untuk BATAN. Laboratorium Pengkajian Teknik Pantai (LPTP) dijadikan sampel untuk BPPT, dan Pusat Penelitian Tenaga Listrik dan Mekatronik sebagai sampel untuk LIPI. Dalam proses penelitian, setelah dilakukan wawancara mendalam dengan kepala LPND, utilisasi SDM dan fasilitas riset dari tiga LPND membentuk inti masalah yang mirip. Karena itu kemudian pada LPTP data penelitian didasarkan atas data sekunder yang tersedia cukup lengkap di websitenya.

Komponen penting yang dieksplorasi dari penelitian ini ada tiga, yaitu:

1. Penilaian utilisasi SDM LPND di bawah KRT

2. Penilaian utilisasi fasilitas riset LPND

3. Pengembangan temuan penelitian menjadi alternatif kebijakan yang disusun dari hasil penelitian terhadap stakeholders dan kajian teoritik yang relevan

\section{TEMUAN DAN ANALISIS HASIL PENELITIAN}

\section{a. Kondisi dan Kualitas SDM}

Secara kuantitatif jumlah SDM di BPPT pada September 2003 sebanyak 2.663 orang atau turun sebesar $1,04 \%$ dari tahun sebelumnya. Hal ini juga terjadi pada BATAN, dimana pada Desember tahun 2002 jumlah SDM-nya sebanyak 3.758 orang. Pada tahun 2003; BPPT sesuai dengan kebutuhan memerlukan tambahan sekitar 50 orang, namun yang dipenuhi berjumlah 17 orang, sementara yang pensiun sebanyak 15 orang. Selain pensiun, ada beberapa staf yang keluar karena berbagai sebab (di antaranya karena brain drain) dan sebagian karena dikeluarkan. Selama dua tahun terakhir staf yang pensiun, keluar, dan dikeluarkan berjumlah 150 orang, sehingga secara keseluruhan jumlah staf di BPPT mengalami penurunan.

Jumlah peneliti pada LIPI adalah 22,91\% (1025) dan 22,28\% (997) selebihnya adalah mereka dengan jabatan fungsional nonpeneliti. Angka ini belum cukup mencerminkan kekuatan sebagai lembaga litbang. Dengan kata lain perbandingan jumlah peneliti dan non-peneliti adalah hampir $1: 5$. Rasio ini bermakna bahwa jumlah SDM non-peneliti masih terlalu banyak. Sesungguhnya komposisi ideal antara tenaga peneliti dan nonpeneliti adalah $1: 2$. Komposisi tidak ideal yang saat ini ditemui disebabkan oleh rekruitmen yang tidak sesuai dengan kebutuhan, atau tidak sesuai dengan kualifikasi yang dituntut oleh lembaga riset.

Usia SDM riset. Di LIPI, usia SDM didominasi $(52,9 \%)$ oleh mereka yang berusia 41-45 tahun dan 46-50 tahun. Apabila tidak ada perubahan, maka 5-10 tahun yang akan datang, jumlah SDM LIPI akan berkurang drastis karena mereka akan segera memasuki usia pensiun. Di BPPT, 36\% dari 2663 pegawai yang bekerja telah berusia 45-55 tahun. Meski range usia yang digunakan berbeda, namun pegawai BATAN jika dilihat 
dari usia juga menunjukkan pola kecenderungan ke arah SDM tua, 63,9\% dari pegawai yang bekerja berusia antara 40 - lebih kecil dari 60 tahun.

Kondisi SDM di BPPT dilihat dari tingkat pendidikan adalah terdapat sebanyak $73,83 \%$ staf yang berpendidikan sarjana dan pascasarjana, baik $\mathrm{S}-1, \mathrm{~S}-2$, dan $\mathrm{S}-3$, sedang selebihnya adalah lulusan Diploma ataupun di bawahnya. Sementara itu, untuk BATAN baru sebanyak $35,68 \%$ yang berpendidikan sarjana (S-1 sampai S-3), sedangkan sisanya di bawah Diploma. Baik di BPPT maupun BATAN, proporsi jumlah tiap jenjang pendidikan terus mengalami perubahan, dimana proporsi staf lulusan S-3 dan S-2 terus meningkat. Sebagai gambaran, pada tahun 2002 staf BPPT yang berpendidikan S-2 hanya sebanyak 690 orang dan S-3 sebanyak 172 orang meningkat menjadi 751 orang untuk S-2, dan 188 orang lulusan S-3 pada tahun 2003. Di LIPI rasio pegawai menurut jenjang pendidikan adalah sebagai berikut: di bawah S-1 $60,3 \%$, S-1 $25,8 \%$, S-2 $9,0 \%$ dan lulusan S-3 $4,8 \%$. Perubahan struktur tingkat pendidikan ini terkait dengan program peningkatan kualitas SDM di lingkungan Ristek yang dimulai sejak tahun 1986 melalui berbagai program studi lanjut berupa OFP, STMDP dan STAID (Science and Technology for Industrial Development).

Di LIPI, angka perbandingan pegawai menurut komposisi jenjang pendidikan antara mereka yang lulusan S-1 ke atas dan di bawah S-1 adalah $1: 2: 5$ yang berarti masih terlalu besar pada pendidikan di bawah $\mathrm{S}-1$. Perbandingan pada kelompok sarjana (S-3 : S$2: \mathrm{S}-1)$ adalah $1: 2: 5$. Komposisi ini akan berubah pada level Kedeputian/Sektama karena ada perbedaan tekanan tugas dan fungsinya, dan juga akan berubah jika dirinci menurut unit kerja di tingkat Pusat dan Biro. Menurut hasil pengkajian STEPI KIST, perbandingan antara S-3 : S-2 : S-1 yang ideal adalah $1: 2: 4$.
Pada tiga LPND yang diteliti, ketidakpuasan pada kualifikasi SDM masih dirasakan. Ketergantungan LPND yang ada dalam koordinasi KRT terhadap Badan Administrasi Kepegawaian Negara (BAKN) adalah salah satu faktor penting di antaranya. Hal ini disebabkan karena kebijakan pengadaan SDM berada di BAKN, dimana proses rekruitmen keahlian masih didasarkan pada tingkat pendidikan. SDM riset membutuhkan karakteristik khas yang idealnya diseleksi oleh LPND sendiri meskipun secara administratif mengikuti aturan kepegawaian BAKN. Merujuk pada UNESCO, keahlian SDM pada suatu bidang bukan hanya didasarkan dari asal dan tingkat pendidikan, namun lebih pada pengalaman kerja. Untuk BPPT dan BATAN, pengelompokan kompetensi belum didasarkan pada pengalaman. BPPT sudah mulai melakukan usaha analisis jabatan, sehingga pengisian jabatan tidak saja dari latar belakang pendidikan namun juga dari sisi pengalaman dan analisa beban kerja.

Kaitan erat SDM riset di LPND dengan BAKN membawa konsekuensi keterkaitan LPND dengan kebijakan zero growth yang ditetapkan pemerintah. Kebijakan ini akan berdampak pada struktur usia yang meningkat menjadi mayoritas golongan usia tua. Akibat lain adalah kekhasan jabatan fungsional peneliti membutuhkan proses magang dan regenerasi yang simultan. Kebijakan zero growth di lingkungan LPND akan menghasilkan lag of generation pada jabatan fungsional peneliti. Belum lagi dengan adanya SDM LIPI misalnya, yang dimanfaatkan oleh lembaga lain, dan memiliki jabatan tertentu di lembaga baru yang dipimpinnya. Terkait dengan ini adalah adanya fenomena "birokratisasi" pada unit riset. Birokratisasi di sini bermakna banyaknya peneliti handal yang karena mekanisme tertentu harus puas dengan jabatan yang tidak terlalu relevan dengan pekerjaan dan ilmu yang diminati.

Kualifikasi SDM ristek dapat juga dilihat dari produktivitas riset, karya paten, jumlah 
prototype dan sebagainya. Sebagai contoh, di BPPT sampai tahun 2002 terdapat 8,5\% dari 646 orang jumlah pegawai fungsional yang mengajukan permintaan paten melalui Biro Umum.

Permasalahan penting yang terkait erat dengan kuantitas dan kualitas SDM adalah problem keterbatasan dana penelitian dan penghargaan secara ekonomis yang minim atau gaji yang belum wajar dengan jabatan fungsional yang dijalankan. Keluhan ini tentu wajar sebab pekerjaan riset tentu berbeda dengan pekerjaan administratif di lembaga pemerintah yang lain, terutama beban keilmuan dan kepakaran yang melekat dalam jabatan fungsional yang disandang. Akibatnya, karena kapasitas individu peneliti di LPND yang cukup baik, memberi peluang kepada mereka untuk mendapatkan lapangan kerja di tempat lain. Hingga tahun 2003, sudah sebanyak 298 orang BPPT yang keluar pindah ke lembaga lain, di antaranya 11 orang eselon I, dan 32 orang eselon Il. Dengan demikian telah terjadi pemindahan SDM unggul ke luar negeri yang secara nasional tentu merugikan program investasi SDM yang telah dilakukan.

\section{b. Kondisi dan Kualitas Fasilitas Riset}

Unit riset yang dimiliki oleh tiga LPND yang diteliti tersebar di banyak daerah di Indonesia. Mulai dari ujung timur sampai ujung barat Indonesia. Lokasi-lokasi tersebut antara lain adalah: Jakarta, Serpong, Bandung, Surabaya, Yogyakarta, Bogor, Garut, Sumedang, Watukosek, Sumbar, Pontianak, Pare-Pare, Manado, Biak, Cibinong, Bali, Ambon, Subang, Lampung, Rumpin, dan masih banyak lagi lainnya. Meski tersebar di banyak lokasi, menurut laporan LPND, peralatan pada unit riset pada umumnya telah berumur cukup tua, sebagian besar berusia 20 an tahun. Akibat lain adalah sebagian laboratorium ada pada posisi "tidak dapat dioperasikan secara optimal".
Prasarana yang dimiliki LIPI dilengkapi dengan sarana-sarana pendukung dan sarana laboratorium untuk penelitian dasar (seperti laboratorium kimia, fisika, fitokimia, fisiologi), penelitian terapan, rekayasa, dan fasiltas laboratorium untuk kalibrasi dan standarisasi. Sedangkan BATAN memiliki berbagai fasilitas utama dan fasiltas pendukung. Untuk fasilitas utama adalah litbang Nuklir yang berada di empat kawasan Pusat Penelitian Teknologi Nuklir (PPTN), yaitu Serpong, Pasar Jum'at, Bandung, dan Yogyakarta. Untuk menunjang fasilitas nuklir utama, tersedia pelbagai fasilitas penunjang antara lain: laboratorium fisika, biologi, radiografi netron, laoratorium NAA dan laboratorium nuklir lain yang dilengkapi dengan peralatan dan instrumen handal. Di antaranya Nuclear Magenetic Resonance (NMR), Gas Permeable Chromatograph (GPC), Mass Spectrometer (MS), Gas Chromatograph - Mass Spectrometer (GC - MS), Atomic Absorption Spectrophotometer (AAS), High Performance Liquid Chromatograph (HPLC), X-ray Fluorescence Spectrometer, Electron Spin Resonance (ESR), Fourier Transform Infra Red (FT-IR), Scanning Elektron Microscope (SEM), Transmition Electron Microscope (TEM), Thermogravimetry Analyzer, Liquid Scintilation, Thermoluminisence Dosimeter (TLD) Reader, dan Small Angle Neutron Scattering (SANS), High Resolution Small Angle Neutron Scattering (HRSANS), Neutron Diffractometer.

Problem utama kajian tentang fasilitas riset pada LPND adalah terbatasnya informasi tentang kondisi dan pemanfaatan fasilitas. Masalah tersebut muncul akibat beragamnya jenis peralatan dan rumitnya indikator penilaian kondisi dan pemanfaatan fasilitas. Awal tahun 2003 KRT melaksanakan survei profil sarana dan prasarana laboratorium yang dikelola oleh LPND di bawah koordinasi KRT. Keterbatasan survei ini terletak pada ukuran kondisi dan pemanfaatan yang didasarkan atas pengakuan pengelola laboratorium. Subyek- 
tivitas pengakuan cukup mengganggu umur fasilitas yang cukup tua. Munculnya penampakan realitas yang sesungguhnya. problem perawatan dan suku cadang tersebut Gambar di bawah ini menunjukkan kondisi disebabkan oleh keterbatasan anggaran dan pemanfaatan fasilitas hasil survei tersebut. perawatan. Perbedaan skema anggaran

Setelah konfirmasi langsung dilakukan, pengadaan yang diperoleh dari Daftar Isian

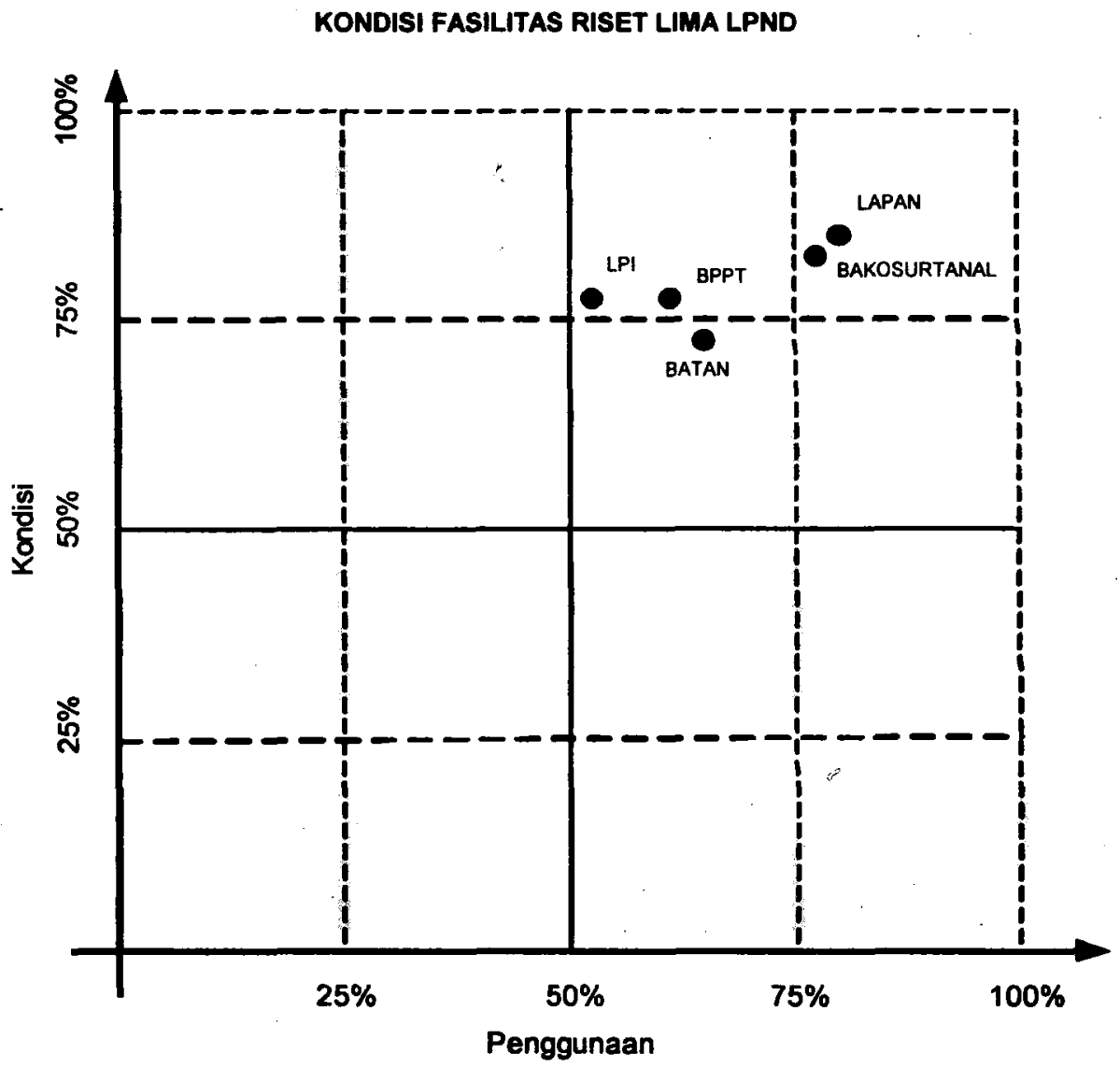

Gambar 2. Kondisi dan Pemanfaatan Fasilitas Riset di LPND-Ristek

tampak bahwa kondisi dan pemanfaatan sebagaimana tergambar di atas cenderung lebih baik dari realitas yang sebenarnya. Fakta yang paling dirasakan pengelola laboratorium atau unit riset adalah banyaknya keluhan seputar suku cadang laboratorium, rendahnya biaya perawatan, dan produktivitas laboratorium yang masih di bawah harapan. Fakta lain yang dikeluhkan pengelola laboratorium adalah
Proyek (DIP) dan perawatan yang bersumber dari anggaran rutin atau Daftar Isian Kegiatan (DIK) menjadi salah satu sebab keterbatasan ini.

Meskipun beberapa LPND sudah mulai mengembangkan kerjasama dengan berbagai pihak yang berkepentingan (stakeholders), namun intensitas dan volume kerjasama tersebut dirasa masih kurang. Kurangnya 
kerjasama antara lain disebabkan masih terbatasnya usaha-usaha sosialisasi produkproduk riset ke masyarakat luas. Memang ada pandangan bahwa sosialisasi dan penjualan produk riset bukanlah tugas utama peneliti (Kompas, 5 September 2003) sebab hal itu akan membebani pekerjaan peneliti. Karena itu perlu dikembangkan manajemen baru untuk mensosialisasikan dan mencari berbagai peluang kerjasama dengan pihak lain.

Sebagaimana problem utilisasi SDM, utilisasi fasilitas riset juga terkait dengan problem anggaran. Terutama yang terkait dengan pengadaan, perawatan dan suku cadang. Sejak krisis ekonomi tahun 1997 proses pengadaan alat tidak sesuai dengan harapan, karena dari kebutuhan yang seharusnya diajukan, tidak semua dapat dipenuhi. Begitu juga mengenai anggaran untuk perawatan dan suku cadang sangat minim. Sehingga masing-masing laboratorium tidak mampu berbuat banyak untuk meningkatkan produktivitasnya.

\section{c. Optimalisasi}

Kompetisi riset merupakan usaha yang dilakukan LPND untuk meningkatkan produktivitas riset para peneliti. Di BPPT paket penelitian kompetitif cukup dikenal, misalnya Riset Unggulan Terpadu (RUT), Riset Unggulan Kemitraan (RUK), Indonesian International Joint Research Program (RUTI), Riset Unggulan Kemasyarakatan dan Kemanusiaan (RUKK). Di LIPI tawaran riset kompetitif dibagi dalam empat jenis penelitian. Keempat jenis penelitian itu dimasukkan dalam tiga kategori. Pertama, ada penelitian kompetitif yang sifatnya top down. Desain penelitian dibuat oleh rapat pimpinan dan dikompetisikan dengan pendekatan multidisipliner atau transdisipliner kemudian melibatkan lebih dari satu pusat riset atau perguruan tinggi. Jenis kedua adalah riset penugasan khusus. Riset penugasan khusus terjadi karena LIPI secara kelembagaan mengadakan kerjasama dengan institusi lain.
Jenis penelitian ke tiga bersifat bottom up, yang kemudian dibagi menjadi dua yang disebut dengan penelitian tematik dan penelitian untuk peningkatan kemampuan individu. Penelitian tematik ini bertujuan untuk memperkuat potensi kelembagaan dari pusat riset. Penelitian tematik ini biasanya muncul dari internal pusat-pusat penelitian dan dia mempunyai pogram sendiri di pusat penelitian. Sedangkan jenis penelitian yang kedua disebut dengan penelitian peningkatan kemampuan individu. Jenis penelitian diadakan untuk meningkatkan kualitas dan kompetensi sumber daya manusia periset yang ada di lingkungan LIPI.

Distribusi jabatan di LPND sampai sekarang masih didasarkan pada tingkat pendidikan tanpa melihat kemampuan dan kebutuhan yang di butuhkan LPND. Untuk itu, dalam pengadaan SDM idealnya menggunakan analisa jabatan. LPND yang sudah membuat analisis jabatan adalah BPPT yang dikenal dengan Perja yang ditetapkan dalam rapat BPPT. Dalam Perja ini diatur dua komponen. Pertama, adalah hal-hal normatif yang berhubungan dengan akibat administratif (DP3, riwayat pegawai, kenaikan pangkat dll). Kedua, aspek kompetensi dengan berdasarkan analisis jabatan dan analisa beban kerja. Dalam analisis jabatan itu akan dipetakan kompetensi yang didasarkan pada pendidikan, pengalaman kerja, dan training. Dengan adanya analisis jabatan ini, masing-masing LPND diharapkan mampu meningkatkan kinerjanya SDM-nya.

Usaha optimalisasi SDM dan fasilitas riset telah dilakukan dengan mendorong unit riset untuk membuka peluang kerjasama dengan dunia industri dan lembaga lain yang relevan. Pada tahun 2002 BPPT misalnya, telah dilakukan kerjasama teknik sebanyak 147 unit dengan berbagai instansi dalam negeri, seperti pemda, perusahaan swasta dan negara, perguruan tinggi, dan yayasan, sedangkan dengan instansi luar negeri sebanyak 12 unit dengan berbagai negara, seperti Amerika, 
Canada, Jepang, Belanda, Italia, Vietnam, dan negara lainnya.

Adanya kerjasama penelitian ini secara konsep akan meningkatkan pendapatan bagi SDM yang ada di lembaga ini. Namun demikian, karena ada ketentuan tentang keuangan negara, dimana semua Penerimaan Negara Bukan Pajak (PNBP) harus dilaporkan dan dimasukkan dalam kas negara melalui Departemen Keuangan (Depkeu). Hal ini menyebabkan kurang termotivasinya SDM LPND untuk mengembangkan kerjasama ini karena tidak ada desentralisasi dalam pengelolaan keuangan di tingkat LPND. Untuk memberi kebebasan berkreasi pada SDM di BPPT dalam menerapkan ilmunya sekaligus meningkatkan pendapatannya, maka administrasi keuangan non pajak untuk bidang riset tidak disamakan dengan departemen/ lembaga lain, dimana desentralisasi pengelolaan keuangan menjadi penting dilakukan, tanpa mengurangi akuntabilitas anggaran tersebut pada negara.

\section{KESIMPULAN DAN REKOMENDASI KEBIJAKAN}

\section{A. Kesimpulan}

Berdasar temuan penelitian dan hasil analisis, maka dapat ditarik kesimpulan sebagai berikut. Pertama, secara kuantitatif SDM pada LPND mengalami problem ketidakseimbangan rasio berdasar jabatan fungsionalnya, terutama pada kategori peneliti dan non-peneliti. Secara kuantitatif angka pertumbuhan SDM peneliti tidak sejalan dengan angka pensiun, sehingga mengakibatkan perubahan struktur usia ke arah usia tua. Di BPPT misalnya, 36\% dari 2663 pegawai yang bekerja sudah berusia 45-55 tahun. Keadaan di LIPI dan BATAN juga tidak jauh berbeda. Kedua, rasio pegawai LPND menurut jenjang pendidikan juga belum memuaskan. Secara umum pegawai yang berpendidikan di bawah sarjana terlalu besar. Rasio pegawai berpendidikan S-3:S-2:S-1 di LIPI misalnya 1 :
2 : 5. Angka tersebut secara gradual perlu dikurangi sampai memenuhi rasio ideal $1: 2$ : 4. Ketiga, kebijakan zero growth untuk SDM peneliti tidak sesuai dengan visi pembangunan IPTEK sebagaimana amanat Undang-Undang No. 25 Tahun 2000 tentang Program Pembangunan Nasional. Keempat, keterbatasan ukuran dan kurangnya ketersediaan data utilisasi fasilitas riset masih belum dapat diselesaikan secara tuntas. Berdasar penilaian yang dibuat KRT, secara makro posisi kondisi dan pemanfaatan fasilitas ada disekitar angka $50 \%$ sampai $75 \%$. Kelima, problem fasilitas riset lainnya adalah lambatnya pengadaan, keterbatasan biaya perawatan dan kurangnya suku cadang. Rendahnya anggaran pengadaan menyebabkan banyak kebutuhan fasilitas riset, biaya perawatan dan suku cadang, tidak dapat dipenuhi. Terpisahnya skema penganggaran pengadaan dan perawatan sering menjadi penyebab bagi munculnya problem disutilisasi fasilitas riset.

\section{B. Rekomendasi Kebijakan}

\section{Bidang Sumber Daya Manusia}

a. Kebijakan Rekruitmen Sumber Daya Manusia

1) Kebijakan rekruitmen SDM kategori peneliti tidak bisa mengikuti pola zero growth. Kebijakan ini dalam jangka panjang akan menciptakan lag of generation pada lembaga-lembaga ristek, termasuk LPND, yang dalam jangka panjang menyebabkan produktivitas peneliti di Indonesia akan terganggu.

2) Memberikan kewenangan kepada tiap LPND dalam proses rekruitmen SDM peneliti, khususnya dalam dari sisi penyaringan kompetensi SDM agar sesuai dengan kebutuhan dan hasil analisis jabatan, sedangkan "“- proses rekruitmen SDM secara administratif tetap yang menjadi kewenangan BAKN. 
b. Kebijakan Reward

1) Perlu dilakukan perubahan sistem pemberian penghargaan/balas jasa/ penggajian pada SDM, dimana tingkat pendapatan yang diterima sekarang ini tidak sesuai (terlalu rendah) dengan sunk cost, kompetensi, dan posisi strategis SDM bidang ristek. Hal ini untuk mencegah terjadinya brain drain yang kontraproduktif dengan tujuan human invesment yang dilakukan oleh negara dalam bidang ristek.

2) Memberlakukan desentralisasi pengelolaan anggaran di tiap LPND, khususnya pada anggaran yang bersumber dari hasil kerjasama/kemitraan LPND dengan pihak lain (pendapatan negara bukan pajak-PNBP). Kebijakan ini perlu dilakukan karena masih minimnya anggaran negara yang teralokasi pada bidang ristek sehingga pola kemitraan yang dikembangkan akan memberikan nilai tambah bagi lembaga riset (LPND) dan personal yang ada di lembaga ini. Desentralisasi pengelolaan anggaran ini dilakukan dengan tetap mengedepankan akuntabilitas anggaran.

\section{c. Kebijakan Optimalisasi Utilisasi SDM}

1) Tiap LPND melakukan langkahlangkah proaktif untuk membangun kemitraan dengan berbagai institusi, seperti perguruan tinggi/ lembaga pendidikan, industri, pemda, lembaga lain di luar negeri, serta ormas/LSM/ yayasan melalui pengembangan dan atau pengadaan divisi khusus kemitraan/ pemasaran di tiap LPND. Munculnya divisi khusus kemitraan ini ditujukan bagi pengembangan kemitraan, dan dapat dilakukan secara proaktif tanpa mengganggu tugas pokok penelitian dari SDM yang ada di unit riset.

2) Melakukan kemitraan antar LPND di bawah ristek, maupun lintas departemen dalam hal perencanaan, pemanfaatan, dan pendanaan riset sehingga terjadi efisiensi anggaran dan optimalisasi pemanfaatan produk riset dari tiap LPND.

3) Produk riset yang dikembangkan oleh tiap LPND selalu diorientasikan guna mendukung tujuan pembangunan nasional, serta sesuai dengan kebutuhan pasar.

\section{Fasilitas Riset}

a. Kebijakan Pengadaan dan Perawatan Fasilitas Riset

1) Penerapan kebijakan perencanaan anggaran dalam pengadaan dan perawatan fasilitas riset yang didasarkan pada Standar Anggaran Belanja (anggaran yang didasarkan pada kebutuhan riil dan harga pasar), sehingga tidak terjadi mark up dan amputasi anggaran yang sering dilakukan dalam proses pengusulan anggaran.

2) Mendukung proses optimalisasi utilisasi fasilitas riset melalui proses kompetisi. Dengan pola kompetisi akan muncul prioritas kebutuhan fasilitas riset. Kebijakan ini perlu dilakukan karena anggaran bidang riset masih minim.

3) Perlu dilakukan penyatuan pos anggaran dalam pengadaan fasilitas riset, termasuk suku cadang dengan anggaran perawatan dari fasilitas tersebut. Hal inj untuk mengeliminasi tidak optimalnya fasilitas riset karena tidak ada anggaran pemeliharaan yang memadai.

\section{b. Kebijakan Optimalisasi Utilisasi} Fasilitas Riset

1) Meningkatkan peran divisi kemitraan untuk mengembangkan kerjasama dengan berbagai institusi, seperti perguruan tinggi/lembaga pendidikan, industri, Pemda, lembaga lain di luar negeri, serta ormas/LSM/yayasan dalam 
pemanfaatan fasilitas yang dimiliki LPND.

2) Mengintesifkan kerjasama pemanfaatan fasilitas riset antar lab di internal LPND, serta lintas LPND guna mendukung efisiensi dan optimalisasi utilisasi dari fasilitas riset yang sudah ada.

3) Mencari dan memperluas lembaga partner sebagai chain agent untuk pemanfaatan fasilitas dan produk riset. LPND memerlukan keberadaan lembaga lain sebagai partner dalam mempromosikan ataupun menjembatani kerjasama pemanfaatan fasilitas dan produk riset.

4) Melakukan kegiatan pemantauan (monitoring) atas produk terapan dari tiap LPND yang sudah ada sehingga produk tersebut berdaya guna untuk kepentingan bidang lain yang lebih luas.

5) Alternatif kebijakan yang dapat diambil untuk mengatasi beratnya beban pengadaan alat adalah dengan menjalin kerjasama dengan swasta dengan memberikan kompensasi tertentu. Skema yang bisa dipilih misalnya pengadaan dan perawatan fasilitas riset oleh pihak swasta, sedangkan LPND menyediakan SDM riset untuk untuk optimalisasi fasilitas baru tersebut. Di pihak lain swasta akan diuntungkan dengan hasil temuan riset yang secara otomatis dapat mereka gunakan sebagai kompensasi atas kontribusi dalam pengadaan fasilitas riset.

\section{DAFTAR PUSTAKA}

Badan Pengkajian dan Penerapan Teknologi. 2002. Laporan Ringkas 2002. Jakarta: BPPT.

Badan Tenaga Nuklir Nasional. 2001. Laporan Tahunan Tahun Anggaran 2001. Jakarta: BATAN.

Badan Tenaga Nuklir Nasional. 2002. Laporan Akuntabilitas Kinerja Badan Tenaga Nuklir Nasional Tahun 2002. Jakarta: BATAN.
Badan Tenaga Nuklir Nasional. 2003. Rencana Strategik BATAN 2020. Jakarta: BATAN.

Certo, Samuel C. 1985. Management of Organizations and Human Resources, Wm. C. Brown Company Publisers, USA.

Dessler, Gary (2000): Human Resource Management, International Edition, 8th Ed. Prentice Hall, Inc., Upper Saddle River, New Jersey.

Dipo Alam (TT). Developing Asia-Pacific Science and Technology Indicators. Science and Technology Task Force: Pacific Economic Cooperation Council.

Erwin Miftah. 2002. "Suatu Pengantar Pendekatan Integratif Audit Atas Sumber Daya Manusia". Majalah Pemeriksa No. 86

Foulkes, Fred K. 1975. Harvard Business Review, March-April

Indocal. 2001. Pelatihan Audit Internal Laboratorium, Kerjasama Indocal Laboratorium System dengan UPT Balai LIN-LIPI, Bandung.

Kantor Menteri Negara Riset dan Teknologi (2001). Pemantauan dan Evaluasi Hasil Program dan Manajemen Riptek Nasional Tahun 1997/1998-1999/2000. Jakarta: KMNRT

Kantor Menteri Negara Riset dan Teknologi (2003). Kebijakan Strategis Pembangunan Nasional Ilmu Pengetahuan dan Teknologi. Jakarta: KMNRT

Keputusan Presiden No. 166 Tahun 2000. Tentang Kedudukan, Tugas, Fungsi, Kewenangan, Susunan Organisasi, dan Tata Kerja Lembaga Pemerintah NonDepartemen.

LAN dan BPKP. (1999). Pengukuran Kinerja Instansi Pemerintah. Jakarta.

Lembaga Administrasi Negara dan Badan Pengawasan Keuangan dan Pembangunan. Evaluasi Kinerja Instansi Pemerintah. Modul Sosialisasi Sistem Akuntabilitas 
Kinerja Instansi Pemerintah (AKIP). Rudy C Tarumingkeng, PhD (2000). "Peran Modul 3 dan 4.

Mardiasmo. 2001. Akuntansi Sektor Publik. Yogyakarta: Andi Offset.

Muhadjir, Noeng. 2003. Metodologi Penelitian Kebijakan dan Evaluation Research. Yogyakarta: Rake Sarasin.

Noviandri, Indra. 2002. Pengelolaan Laboratorium, Makalah Pelatihan Tenaga Teknisi/Laboran, 2 September - 3 Oktober 2002, Bandung.

Pusat Penelitian dan Pengembangan Teknologi Maju, Badan Tenaga Nuklir Nasional. 2003. Laporan Triwulan II Bulan AprilJuni Tahun Anggaran 2003. Yogyakarta: BATAN.

Pusat Penelitian Tenaga Listrik dan Mekatronik (PUSTELIMEK-LIPI). 2002. Laporan Tahunan PUSLIT TELIMEK-LIPI tahun 2002. Bandung: PULIT TELIMEKLIPI. Strategis Manajemen Sumber Daya Manusia". Makalah Kuliah Perdana pada Program Pasca Sarjana - Magister Manajemen, Universitas Kristen .Krida Wacana.

Suryadi, Ace dan Tilaar, HAR. 1993. Analisis Kebijakan Pendidikan: Suatu Pengantar. Bandung: Rosda Karya.

Zuhal. 2000. Visi IPTEK Memasuki Milenium III. Jakarta: UIP

Kompas, 5 September 2003. Quo Vadis SDM Teknologi Kita? 